\title{
O Agente Diplomático
}

\author{
G. E. Do Nascimento E Silva \\ Diplomata. Professor do Instituto de Altcs \\ Estudos Internacionais da Universidade de \\ Paris. Secretário da Comissão Nacional de \\ Codificzção do Direito Internacional.
}

\section{I - CONCEITO DE AGENTE DIPLOMÁtICO}

$\mathrm{O}_{\mathrm{s}}$

agentes diplomáticos são, na definição de Clovis BEVILÁQUA, "as pessoas acreditadas pelo Govêrno de um Estado, perante o Govêrno de outro, para representar os seus direitos e interêsses". (1)

\section{II - CLASSIFICAÇÃo DOS AGENTES DIPLOMÁTICOS}

No estudo de classificação dos agentes diplomáticos é necessário fazer uma distinção entre os chefes de missão e os demais funcionários da mesma.

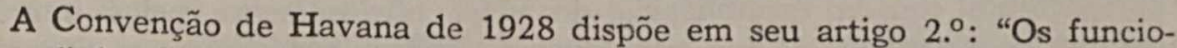
nários diplomáticos dividem-se em ordinários e extraordinários. São considerados ordinários os que representam de maneira permanente o Govêrno de um Estado perante outro. São extraordinários os encarregados de missão especial, ou os que se acreditam para representar o Govêrno em conferências, congressos ou outros organismos internacionais".

Conforme nota GuSTAvo GuerRero "o que a convenção chama agentes ordinários são os agentes diplomáticos pròpriamente ditos. Os agentes extraordinários só são diplomatas por extensão". (2) Aqui só nos ccuparemos dos diplomatas pròpriamente ditos, isto é, dos agentes diplomáticos ordinários.

Hoje em dia a doutrina não hesita em acolher a classificação resultante do Regulamento de 19 de março de 1815 do Congresso de Viena com a modificação trazida em 1818 pelo Protocolo firmado em Aix-la-Chapelle. Nos têrmos do Regulamento de Viena "les employés diplomatiques sont partagés en trois classes:

a dos embaixadores, legados ou núncios;

a dos enviados, ministros ou outros acreditados junto aos soberanos; a dos encarregados de negócios, acreditados junto aos Ministros encarregados dos Negócios Estrangeiros.

A fim de evitar conflitos de precedência, incluiu-se em Aix-la-Chapelle, depois dos Ministros de segunda classe e antes dos encarregados de negócios, 
os Ministros residentes. Essa denominação surgiu da circunstância de a prática de manter missões diplomáticas permanentes não haver sido logo acolhida e, assim, quando um enviado tinha que permanecer por muito tempo recebia o título de Residente. Posteriormente, com a aceitação das legações permanentes a denominação Ministro Residente perdurou. Dada a confusão existente entre os Ministros de segunda classe e os Ministros Residentes, o Protocolo de Aix-la-Chapelle veio colocá-los abaixo daqueles.

Outro acréscimo ao Regulamento de Viena foi o dos Internúncios, que figuram hoje em dia juntamente com os Ministros Plenipotenciários.

Os enviados da Grã-Bretanha aos Domínios britânicos se intitulam, em virtude de velha tradição, Altos Comissários (High Commissioners). Êsse mesmo título é dado pelos Domínios aos seus representantes na Côrte de Saint James, donde não haver uma capitis diminutio. Os Altos Comissários são verdadeiros embaixadores e se por acaso coincidir que um seja dentre os embaixadores o mais antigo, será o Decano do corpo diplomático local.

Finalmente, é necessário mencionar a recente prática de enviar representantes diplomáticos, cujo uso surgiu nos primeiros anos posteriores à ultima grande guerra. Certos países, cuja situação internacional não se achava ainda definida decidiram enviar êsses representantes que, sem possuirem os títulos dos demais, passaram a figurar na lista diplomática logo depois dos encarregados de negócios ad hoc. O seu uso tem se difundido e hoje em dia é lícito dizer que os representantes diplomáticos representam um primeiro passo para a manutenção de relações diplomáticas normais. A Grécia, por exemplo, que não outorgou um reconhecimento de jure a Israel tem em Jerusalem um, representante com a incumbência de velar oficiosamente pelos interêsses hastante consideráveis de seu país, dada a existência de inúmeros santuários e congregações da Igreja grego-ortodoxa na Terra Santa.

Resumindo, pode-se dizer que hoje em dia os chefes de missão podem ser de uma das seguintes cinco categorias: embaixadores (e Altos Comissários) legados e núncios; ministros plenipotenciários e internúncios; encarregados de negócios ad hoc; representantes diplomáticos; e encarregados de negócios ad interim.

Atualmente, as diferenças entre os Embaixadores e Ministros são sobretudo de precedência e etiqueta. Dispõe o Regulamento de Viena, no art. 2. que "só os embaixadores, legados ou núncios têm o caráter representativo" (les ambassadeurs, légats ou nonces ont seuls le caractère representatif). Era intenção dos signatários reservar a nomeação dos embaixadores às potências de primeira grandeza, isto é, àquelas que gozavam de "honras reais". Mesmo na época o dispositivo foi combatido por KLUBER (1819) e PINHEIRO FERREIRA como "ficção inaceitável". O diplomata representa o Estado, não o soberano. A Convenção de Havana, a fim de afastar possíveis dúvidas, dispõe na preâmbulo que os funcionários diplcmáticos não representam en: caso algum a pessoa do Chefe de Estado e sim o seu Govêrno e devem estar acreditados junto a um Govêrno reconhecido. No tocante aos núncios, porém, trata-se de representantes do $\mathrm{Papa}$; não da Cidade do Vaticano.

Considerando que as funções, prerrogativas e imunidades dos agentes diplomáticos das três primeiras classes (embaixadores, Ministros Plenipoten- 
ciários e Ministros Residentes) são as mesmas, a doutrina e alguns Estados têm se revoltado contra essa prática que, no fundo, fere um dos princípios básicos do direito internacional, ou seja o de igualdade jurídica dos Estados. Em conseqüência tem-se advogado a adoção de um título comum a todos os chefes de missão portadores de credenciais firmadas pelo Chefe de Estado.

$\mathrm{Na}$ reunião da Comissão Internacional de Jurisconsultos Americanos, reunida no Rio de Janeiro em 1927, para elaborar os projetos a serem examinados no ano seguinte em Havana, o delegado colombiano propôs a abolição do título de embaixador por ser contrário ao espírito democrático. JAMES BRown ScotT, delegado dos Estados Unidos, defendendo a atitude de seu Govêrno na questão, salientou que o mesmo "para não ficar em uma posição de inferioridade em relação a Estados europeus, resolveu criar embaixadores nesses Estados". Acrescentou estar pessoalmente de acôrdo com o que se dissera a respeito do sistema diplomático, mas lembrou que a finalidade da reunião era codificar o direito internacional e não discutir questões de ordem política.

Finalmente, a Comissão julgou preferível evitar a adoção de um artigo expresso a respeito.

No mesmo ano, a Comissão de Peritos para a Codificação do Direito Internacional, da Liga das Nações, submetia um Relatório aos Estados membros no qual o Relator, Doutor Gustavo GUERRERo, opinava que se deveria englobar numa só classe, com a mesma designação, todos os agentes diplo+ máticos, excetuados os encarregados de negócios. Oito dos vinte e sete governos consultados pronunciaram-se favoràvelmente; quatro apresentaram objeções e onze se opuseram formalmente. Em consequêencia a Comissão de Peritos deu por encerrado o assunto.

A Rússia Soviética, porém, em virtude de decreto do Conselho dos Comissários do Povo, de 4 de junho de 1918, renunciou de sua parte ao disposto no Regulamento de Viena, admitindo uma categoria uniforme para todos os seus agentes diplomáticos no exterior: êstes são denominados representantes plenipotenciários. Contudo, a fim de evitar certas dificuldades nas questões de precedência, o Govêrno soviético adotou a prática de indicar entre parêntesis, nas credenciais, depois das palavras "representante plenipotenciário" a classificação do agente de acôrdo com o Regulamento de Viena. (3)

Os encarregados de negócios podem ser de dois tipos: ad hoc, quando chefiam uma legação (nunca embaixada) a título permanente; ou ad interim, quando ocupam a direção de uma embaixada ou legação na ausência do titular efetivo.

\section{III - O PESSOAL OFICIAL E NÃO OFICIAL DA MISSÃO}

As missões diplomáticas compõem-se, além do respectivo titular, do pessoal oficial e do pessoal não oficial.

O pessoal não oficial compreende a família dos funcionários de carreira e seus secretários e criados particulares.

O pessoal oficial pode ser classificado em três grupos: no primeiro temos os funcionários diplomáticos (conselheiros e secretários de embaixada ou lega- 
ऽão); no segundo os adidos militares (militar, naval e aéreo) e civis (comerciais, culturais, de imprensa, etc.); e no terceiro o pessoal administrativo (dactilógrafos, arquivistas, criptógrafos, intérpretes, correios, etc.) que não figura na lista diplomática.

O substituto eventual do chefe da missão será sempre um funcionário de carreira mesmo se houver na embaixada um adido de maior categoria.

\section{IV - NOMEAÇÃO DO AGENTE DIPLOMÁTICO PARA SERVIR NO EXTERIOR}

Cabe ao direito interno fixar as normas relativas à nomeação dos agentes diplomáticos, ou conforme diz a convenção de Havana de 1928: "Os Estados são livres na escolha dos seus funcionários diplomáticos..."

O ingresso na carreira diplomática dá-se normalmente na classe inicial (no Brasil trata-se de imperativo constitucional) e, portanto, por "nomeação do agente diplomático" teremos em vista o do chefe de missão.

Dois são os sistemas seguidos na escolha dos embaixadores e ministros: ou se envia funcionário de carreira que já tenha reunido as condições necessárias para servir em tal capacidade ou se recorre a indivíduos estranhos à carreira, possuidores - em teoria — de atributos que tornam a sua nomeação indicada.

Não obstante existirem algumas raras exceções à regra, a prática ensina que a nomeação de embaixadores fora dos quadros diplomáticos é quase sempre desaconselhável, já que a experiência na diplomacia é um dos mais importantea requisitos.

No Brasil, os ministros plenipotenciários são sempre de carreira; quanto aos embaixadores "excepcionalmente, a nomeação poderá recair em pessoa estranha à carreira de "Diplomata", brasileiro nato, maior de 35 anos, de reconhecido mérito e com relevantes serviços prestados ao Brasil" (Decretolei n. 9.020 , de 26 de abril de 1946, art. 5.,$\S 1^{\circ}$ ).

De um modo geral, a administração pública brasileira é avêssa à nomeação de embaixadores de ocasião, tanto assim que o Presidente EuRICo GASPAR DUTRA, ao ser empossado, dispensou os poucos que havia na nossa organização. Ainda recentemente, o Senado Federal, no exame de uma nomeação submetida à sua apreciação, consultou ao Executivo sôbre quais as suas razões na escolha, visto que havia na ocasião diplomatas de carreira aptos a ocuparem a embaixada.

\section{V - O AGRÉMENT}

Antes de nomear um chefe de missão, é de praxe consultar em caráter confidencial ao govêrno onde o mesmo irá servir se o indigitado é ou não persona grata, isto é, se será bem recebido como enviado diplomático.

A Convenção de Havana se ocupa do pedido de agrément em seu art. $8 .^{\circ}$ : "Nenhum Estado poderá acreditar os seus funcionários diplomáticos ante os outros Estados, sem prévio acôrdo com êstes. Os Estađos podem negar-se a admitir um funcionário diplomático de outros, ou já tendo admitido, pedir a sua retirada, sem ficarem obrigados a explicar os motivos da sua resolução." 
Hoje em dia a consulta prévia é de praxe e nenhum Estado seria capaz de enviar um Chefe de Missão sem proceder antes a essa formalidade.

Nem sempre, contudo, a aǵréation foi tida como indispensável. BluntsCHLI no seu Le Droit International Codifié, por exemplo, não faz refèrência à prática. O Govêrno dos Estados Unidos era avêsso a se certificar da disposição de um Govêrno estrangeiro para com um indivíduo a ser acreditado junto a êle como Embaixador". (4) Em 1885, o Govêrno austro-húngaro chamou a atenção do Govêrno dos Estados Unidos para "a prática diplomática geralmente admitida de se solicitar antes da nomeação de um Ministro estrangeiro o agrément do Govêrno junto ao qual será acreditado". Em sua resposta, o Secretário de Estado se justificou dizendo "nenhum caso pôde ser encontrado nos arquivos do Departamento de Estado em que a conveniência de se aceitar um enviado fôsse investigada ou confirmada anteriormente à sua nomeação para a missão para a qual foi escolhido e há motivos, decorrentes das frequientes eleições e câmbios administrativos nos Estados Unidos, porque a prática não deva ser adotada". (5) Hoje em dia, contudo, não há dúvida de que os Estados Unidos aceitam como lei internacional a consulta prévia.

A prática de indagar com anterioridade se o indigitado conta ou não com o beneplácito do govêrno do país onde irá servir nasceu da conveniência. Se bem que os Estados devem acolher os enviados das nações amigas, isto não significa que estão obrigados a admitir qualquer um. Seria inclusive contraproducente a um país ter por representante um indivíduo malquisto em outro e que, possivelmente, no passado, tivesse assumido uma atitude contrária ao país para o qual foi designado. Isto sem falar na possibilidade do mesmo nem ser recebido.

A consulta em aprêço só é feita no tocante aos embaixadores, ministros e encarregados de negócios ad hoc. Alguns países (Brasil, França, Argentina, Bélgica, Espanha, Estados Unidos da América, Paraguai, Polônia e Portugal) exigem ainda a consulta prévia para os adidos militares, navais e aéreos; enquanto que outros, nesse particular, adotam o princípio da reciprocidade. (6)

O pedido de agrément é quase sempre feito através da missão diplomática do respectivo país. Excepcionalmente, poderá ser feito diretamente de país a país ou através da Embaixada ou Legação do país onde o diplomata irá exercer a sua missão. O pedido é feito pelo chefe da missão (o titular a ser substituído ou pelo encarregado de negócios interino), ao Ministro das Relações Exteriores ou ao Secretário Geral, entregando-se na ocasião a fé de ofício do indigitado. O pedido poderá ainda ser feito por nota ou nota verbal endereçada ao Ministério das Relações Exteriores.

De posse da consulta, a Secretaria de Estađo poderá solicitar esclarecimentos suplementares à sua missão diplomática no país onde o agente se encontra ou se contentará com os dados fornecidos na fé de ofício.

Pela maneira conn que é concedido o agrément, pode um Estado demonstrar a sua satisfação, ou não, no tocante ao nome do diplomata. Quando deseja frisar o seu aprêço pela pessoa do nomeado, concede-o ato contínuo. Se não tem semelhante empenho, deixa o caso seguir seus trâmites ilegais e, baseado nas informações, responde no prazo aproximado de uma semana. Se porven- 
tura tem restrições quanto à pessoa indicada, mas, a fim de não ferir melindres, não deseja ir ao ponto de negar seu beneplácito, evita, de uma maneira ou outra, dar uma solução ao caso, protelando a resposta. (7)

De posse da resposta favorável, o respectivo Govêrno lavrará o decreto de nomeação. No Brasil, como em diversos outros países, a nomeação dependerá ainda de outra formalidade: nos têrmos do art. 63, I, da Constituição de 1946, "compete privativamente ao Senado Federal: aprovar, mediante voto secreto, a escolha... dos chefes de missão diplomática de caráter permanente". Não é difícil compreender a mens legis do preceito constitucional. BARBALHO, um dos principais comentadores da nussa Constituição de 1891, assim se pronunciou a respeito: "Trata-se do provimento de cargo de tão elevada hierarquia que cumpre fazê-lo com cautelas tais que possam evitar quaisquer abusos e facilidades na escolha. E muito mais fàcilmente êstes poderão ocorrer sendo ela abandonada ao Presidente, sem algum contraste, sem fiscalização. Como corretivo, associou-se o Senado a esta função de altíssima importância". (8)

Discutiu-se no Brasil sôbre se sòmente a escolha dos Embaixadores e Ministros acreditados perante Governos estrangeiros estava sujeita à aprovação do Senado ou se essa era de rigor no tocante às nomeações dos Delegados permanentes perante as Nações Unidas e outros organismos internacionais. Parece-me que sim, pois, conforme lembrou o Senador ARTHUR SANTos em trabalho sôbre a matéria, "a contrariu sensu, chegar-se-ia ao absurdo de admitir a necessidade da aprovação do Senado para a designação do agente diplomático brasileiro junto ao Paquistão ou ao Iraque e dispensar essa exigência para o nosso representante no Conselho de Segurança das Nações Unidas ou na União Pan-Americana. Entretanto naqueles países pouca ou nenhuma será a conseqüência advinda dos atos praticados pelo nosso Delegado; nestas organizações, ao revés, elas dispensam comentários". (9)

Conforme vimos, o parágrafo único do artigo $8^{\circ}$ da Convenção de Havana dispóe que os Estados podem livremente negar-se a aceitar um chefe de missão indicado por outro "sem ficarem obrigados a explicar os motivos da sua resolução". A razão de semelhante ressalva é que a concessão do aǵrément deve ser inteiramente livre e a obrigação de prestar esclarecimentos seria um entrave a esta liberdade. Se bem que os Governos não sejam obrigados a explicar a razão de sua escusa, essa é freqüentemente dada, a bem das boas relações existentes.

Segundo P. FAUChille, (10) repetido por inúmeros outros autores, sòmente a Inglaterra exige que o Govêrno estrangeiro the inteire das razões que o levaram a recusar o enviado por êle indicado. Ela nâo se contenta com a objeção baseada na falta de confiança; exige a indicação de fatos positivos, baseados ra conduta anterior do Ministro público. E de se notar contudo que duas das mais categorizadas autoridades britânicas, Sir ERNEST SATOw e OPPENHEIM, (11) dizem claramente que o Estado não está obrigado a revelar a natureza de suas objeções, nem justificá-las.

MARCEL SiBERT, ocupando-se da questão, salienta que "o agrément só pode ser um ato inteiramente livre: o menor constrangimento exercido por quem quer que seja o torna inexistente". E acrescenta: "o fato de que näo 
tivesse sido concedido teria como conseqüência de privar o interessado da qualidade de agente diplomático e dos privilégios e das imunidades conseqüentes. Em 1950, a Côrte de Cassação francesa reconheceu esta verdade quando OTTо ABETZ invocou a sua qualidade contra a condenação penal com que foi atingido pelos crimes de que fôra autor durante a ocupação de Paris de 1940 a 1944". Pensamos, porém, que o ilustre catedrático de Paris, pautando-se no exemplo acima mencionado de OTTO ABETZ, exagerou o alcance da ausência do agrément. Se um diplomata fôsse enviado a um pass sem 0 pedido anterior de agrément (hipótese quase impossivel), a falta de aprovação prévia seria sanada pela aceitação de suas credenciais.

Seja como fôr, isto não impede que em certas circunstâncias, diante da recusa de um seu diplomata, um Estado possa se melindrar, daí surgindo uma tensão entre dois governos, permanecendo a missão ou as missões entregues por longo perícdo a encarregados de negócios.

Rubens de Mello lembra que em 1926 o Govêrno brasileiro recusou o agrément a Monsenhor BEDA CARDinale, para Núncio Apostólico no Rio de Janeiro, a fim de não ser desagradável ao Govêrno argentino, visto o mesmo haver deixado poucos meses antes a Nunciatura Apostólica na Argentina, onde se tornara persona non grata, por haver-se indisposto com o Arcebispo de Buenos Aires. A Santa Sé relutou em aceitar'a recusa e esteve a pique de enviar um Delegado Apcstólico para o Rio de Janeiro, o que implicaria numa suspensão das relações diplomáticas com o Brasil. Graças à ação do Embaixador brasileiro junto zo Vaticano, CARLos MAGalHães DE AzERELo, o incidente foi evitado: a Santa Sé indicou o nome de Monsenhor (hoje Cardeal) BENEDETto Aloise Masella, e o Brasil, desejoso de dar uma prova de seu empenho em pôr têrmo ao caso, acolheu ato contínuo a indicação. (13)

Pode suceder que, após haver recebido uma resposta favorável a um pedido de agrément, um govêrno decida enviar outro chefe de missão que não aquêle indicado inicialmente. Naqueles países em que a nomeação dos Embaixadores e Ministros depende de aprovação do Senado, semelhante fato pode ccorrer. À primeira vista, diante de semelhante possibilidade, seria o caso de só se solicitar o agrément após a aprovação no Senado. Sucede que a boa prática manda que durante as negociações deve ser mantido o máximo sigilo já que qualquer indicação pode ser interpretada como uma pressão, pressão esta que seria até prejudicial no caso de haver uma sanção do Legislativo.

Geralmente, quando um Estado, após haver recebido agrément para um diplomata, indica o nome de outro, age dêsse modo por doença do primeiro, necess:dade de the confiar outro pôsto, razões de política interna ou por haver ocorrido fato grave com a pessoa do mesmo. "Em abril de 1947, o Govêrno britânico comunicou ao Govêrno brasileiro que o Senhor VICTOR FREDERICH WILLIAM CAVENDISH-BENTINCK, para o qual havia solicitado e obtido o necessário agrément para Embaixador no Brasil, não assumiria seu pôsto. Motivou essa atitude do Govêrno britânico, da qual, aliás, não teve necessidade de dar explicações, o fato de a ação de divórcio, movido pelo Sr. CAVENDISH BENTINCK contra a sua espôsa, haver sido julgado de forma pouco lisonjeira para êle". (14) Em casos desta natureza seria lícito dizer que ao indicar novo nome 
- Govêrno dá uma prova de deferência ao outro, evitando mandar um agente que não desfrutaria de boa situação local.

Seja como fôr, ocorrendo mudança na escolha, o Govêrno interessado deverá dar uma explicação satisfatória ao outro Govêrno.

\section{VI - MEDIDAS A SEREM TOMADAS PELO DIPLOMATA ANTES DE SUA PARTIDA}

Uma vez efetuada a sua nomeação, o agente diplomático deverá efetuar uma visita de cortesia ao chefe da missão onde irá servir, visita esta que the será ainda útil já que poderá solicitar de seu colega uma série de informações de que carece.

A partir de então deverá tornar-se conhecedor das instituições do país onde irá servir, sua história e geografia e das relações existentes entre o país que representa e onde servirá. Estando na Secretaria de Estado (Quai d'Orsay, Foreign Office ou Itamarati), a sua tarefa será mais fácil já que poderá coilsultar tôda a correspondência recebida da missão que irá chefiar, além de pedir tôdas as instruções necessárias aos diversos chefes de departamento e divisão.

Finalmente, deverá se munir de sua credencial, cópia figurada da mesma, passaporte diplomático e, se hecessário, de um laissez-passer. Outrora, o diplomata levava ainda as instruções escritas, nas quais se achavam expostos minuciosamente os passos a serem tomados na solução de casos pendentes. Hoje em dia, contudo, dadas as facilidades de comunicações telegráficas e aéreas, o diplomata recebe, apenas, instruções verbais.

RaOul Genet diz ainda que o diplomata deverá se munir dos necessários códigos telegráficos. (15) A não ser no caso de uma instalação de missão diplomática, êstes, normalmente, já se encontrarão na missão. entregues ao encarregado de negócios. $E$ bem verdade que, em muitos países, os códigos podem ser fàcilmente modificados por meio de "complicadores".

\section{VII - AS CREDENCIAIS}

O mais importante dentre os documentos que o agente diplomático leva consigo é a credencial, designada geralmente no plural credenciais (lettre de créance, em francês, letter of credence em inglês, ou litterae fidei em latim).

E o documento pelo qual o agente diplomático é acreditado por soberano ou Presidente perante o Chefe do Estado onde irá exercer as suas funções e no qual se acham indicados o seu nome, categoria e missão, terminando invariàvelmente com o pedido de que se dê ao titular fé e crédito para tudo que diga.

A credencial, firmada pelo Chefe de Estado e referendada pelo Ministro das Relações Exteriores, é confiada fechada e selada ao Embaixador ou Ministro e assim deve ser entregue ao Soberano ou Presidente a que se destina. Junto com a credencial, o agente recebe uma cópia figurada da mesma (copie figurée), que ao contrário do original the é entregue aberta para ser transmitida ao Ministro das Relações Exteriores na prin.eira audiência. 
Freqüientemente, o diplomata leva consigo a revocatória (lettre de rappel), documento pelo qual o Chefe de Estado explica o motivo da terminação da missão de seu antecessor. Em teoria, êste documento deveria ser cntregue pelo próprio, mas na prática tal raramente se dá.

Só os Embaixadores, Ministros Plenipotenciários e Ministros Residentes são munidos de credenciais (as dos Núncios e Internúncios têm a forma de Bulas).

As credenciais dos encarregados de negócios ad hoc são menos solenes: têm a forma de uma nota dirigida pelo Ministro das Relações Exteriores ao titular do outro país junto ao qual é acreditado.

O encarregado de negócios interino não recebe credencial: é geralmente acreditado por nota do titular que se retira (definitiva ou provisòriamente). Poderá ainda ser acreditado por nota ou por telegrama de um Ministro das Relações a outro, ou, caso raro, por intermédio da missão diplomática do país onde êle se encontra, a pedido do respectivo Ministro das Relações Exteriores.

Ocorrendo mudança de Chefe de Estado, é necessário nova credencial? Conforme vimos, a credencial é o documento pelo qual um agente diplomático é acreditado por um Chefe de Estado perante outro. Daí, à primeira vista, ser necessário novo documento. Nesse particular devemos voltar à questão do caráter representativo dos agentes diplomáticos. As monarquias, que continuam a considerar os respectivos enviados como representantes da pessoa do soberano, exigem nova credencial no caso de mudança por morte, renúncia ou deposição. Em outras palavras, os agentes do novo soberano no exterior deverão fazer chegar ao Chefe de Estado suas novas credenciais e os diplomatas acreditados no país deverão fazer o mesmo. Nesse caso, contudo, não haverá apresentação solene de credenciais nem modificação na ordem geral de precedência.

As Repúblicas não exigem novo documento, se bem que nas suas relações com as Monarquias concordem em expedir ou aceitar novas credenciais no caso vertente. A razão é simples, pois, conforme estipula a convenção de Havana, de 1928, "os funcionários diplomáticos não representam em casc algum a pessoa do Chefe de Estado, e sim o seu Govêrno". Ou como ensina Accioly.

“o outorgante dos poderes não é pròpriamente o Chefe de Estado mas sim o próprio Govêrno do país, que é impessoal. O Chefe de Estado é simplesmente a autoridade que representa o Estado ou o Govêrno nas suas relações externas." (16)

FAUCHILle, baseado num fato concreto, ensina que novas credenciais são de rigor no caso de mudança na forma de govêrno do pais. E neste casu, a precedência dos agentes é fixada pelas novas credenciais? FAUCHILLE, reportando-se à revolução ocorrida na Alemanha depois da Segunda Guerra Mundial cita o exemplo da Venezuela onde VoN PRollius, que era Ministro da Alemanha depois de janeiro de 1911, não apresentou novas credenciais. Um grupo de jurisconsultos aliados, consultados pelo Conselho da Liga das Nações, 
opinou no sentido de que a apresentação de novas credenciais não modifica em nada a precedência de um chefe de missão, mas que a não apresentação de novas credenciais faz com que perca a qualidade necessária para que possa representar legalmente o seu país, até então sob um outro Govêrno. (17)

Os casos citados por FAUCHILle são de mudança de forma de Govêrno, isto é, de transformação de Monarquia em República, caso êste em que ocorre verdadeira metamorfose. Mas no caso de ocorrer mudança apenas dos dirigentes e não na forma de govêrno? Pensamos que ocorrendo a mesma em República não se deve exigir novas credenciais; de qualquer maneira os Embaixadores ou Ministros do país onde ocorreu a revolução só serão conservadns se gozarem do beneplácito das novas autoridades.

A recepção do Embaixador ou Ministro pelo Soberano ou Presidente da República constitui o reconhecimento oficial como representante de Estado amigo. Ainda hoje a entrega das credenciais é uma cerimônia assaz solere, sobrevivência da época em que o enviado diplomático representava a pessoa do seu soberano e, em conseqüência, merecia as mesmas honras que deveriam ser tributadas a êste. A cerimônia varia de país a país e o diplomata recémvindo é devidamente instruído pelo protocolo acêrca da mesma. Ao chegar o diplomata deve solicitar audiência ao Ministro das Relações Exteriores para entregar a cópia figurada de suas credenciais. Nessa ocasião pede que seja marcado dia e hora para a entrega solene do original. No dia é buscado na sede da Missão em carro de Estado sendo organizado um cortejo que, precedido pelo coup-file, se dirige ao palácio Real ou Presidencial onde será efetuada a entrega solene das credenciais. Em muitos países é de praxe que o enviado pronuncie um discurso formal contendo exclusivamente expressões de cortesia e no qual o leit motiv será o estreitamento dos laços de amizade entre as duas nações. A resposta do Chefe de Estado deve ser calcada, parágrafo por parágrafo, na do enviado.

As credenciais são apresentadas na Capital do Estado onde o diplomata irá exercer as suas funções, mas excepcionalmente a mesma poderá se efetuar alhures. Hoje em dia nos países em que, devida à canícula, o Chefe de Estado tem por praxe retirar-se da capital para uma cidade de veraneio, é frequiente que a cerimônia se efetue na mesma. onde é ela levada a efeito no verão, em Petrópolis, no Palácio Rio Negro. Pode ainda suceder, se assim o exigirem as circunstâncias, em qualquer outro ponto do território nacional. Em 1867, o Ministro britânico apresentou as suas credenciais ao IMPERADOR PEDRO II, no Brasil, em Uruguaiana, onde o soberano acabava de receber a rendição de um corpo do exército paraguaio.

Por fim é de interêsse lembrar o caso de Jerusalém, proclamada por Israel como sua capital mas que não é reconhecida como tal pelos Estados que votaram nas Nações Unidas pela Internacionalização da Cidade Santa. Durante a vida do Presidente WeIzMAN não surgiu nenhuma questão no concernente à apresentação de credenciais visto que o mesmo, por razões de saúde, residia em Rehovot, cidade próxima a Tel-Aviv. Atualmente, que o novo Presidente de Israel se cstabeleceu em Jerusalém, o problema tem sido mais controvertido. Mas no caso do Ministro da Itália, por exemplo, aproveitou-se a circunstância do Presidente passar alguns dias numa estação de vilegiatura para aí se efetuar a cerimônia. 
A partir da apresentação das credenciais o Embaixador ou Ministro gozará integralmente do caráter diplomático com as conseqüentes prerrogativas e imunidades. Antes dêsse momento será considerado como estando incógnito no país, tanto assim que ao chegar não será recebido com cerimônia oficial: será auxiliado ao máximo em tudo, mas a título oficioso.

\section{VIII — TÊRMO DA MISSÃO DIPLOMÁTICA}

Variam as maneiras pelas quais pode findar uma missão diplomática. De um modo geral, os autores limitam-se a enumerar as mesmas, sem entrar em maiores detalhes.

A nosso ver semelhante atitude é suscetível de críticas, pois, não se pode considerar como fenômeno do mesmo gênero a terminação da missão diplomática em virtude da extinção do Estado da que ocorre pela mera transferência do titular a novo destino.

Dentro dessa orientação, pensamos .que se deve estudar separadamente os casos de terminação ou interrupção no exercício do direito de legação dos casos de fim da missão do agente diplomático.

\section{IX — EXTINÇÃO E INTERRUPÇÃO DO DIREITO DE LEGAÇÃO}

A apreciação dos casos de extinção e interrupção do direito de legação se acha estreitamente vinculada à questão do exercício do direito de legação. Nesse particular o princípio básico é de que em princípio só os Estados soberanos gozam do direito de legação e, contrariu sensu, a perda dessa qualidade implicará na perda desse direito.

Assim, se um Estado soberano é anexado ou passa a ser um protetorado, perde, em princípio, o direito de legação e termina a missão diplomática. Mas existem exemplos em contrário. Assim, os Estados Bálticos - Estônia, Letônia e Lituânia - apesar de anexados pela U.R.S.S. continuam a ter os seus representantes aceitos naqueles países, como o Brasil, que não reconheceram a referida anexação. É bem verdade que para a Rússia não houve igualmente, mas por outros motivos, a extinção do direito de legação, visto que passaram a ser três Repúblicas socialistas e soviéticas dentro da U.R.S.S., em igualdade de condições, portanto, com a Ucrânia e Rússia Branca, ambas admitidas como Estados independentes nas Nações Unidas. Mas a tese russa não passa de ficção, pois não há a menor dúvida de que nenhuma das Repúblicas componentes da grande U.R.S.S. goza do nenor resquício de independência.

De igual maneira, a passagem de um Estado Soberano à categoria de protegido deve acarretar a perda do direito de legação; mas no caso da Tunísia e do Marrocos (hoje plenamente soberanos), ambos conservaram direito restrito de legação passivo. (18)

Haverá interrupção no exercício do direito de legação quando ocorrer uma ruptura pura ou simples de relações diplomáticas ou quando a ruptura é consequêencia de um estado de guerra entre os dois países interessados. (19) 
Nesses dois casos não ocorre, a rigor, uma interrupção do direito de legação: suprime-se o contato direto entre as partes; contato êste que subsiste através dos Estados encarregados da proteção de seus interêsses.

\section{X — FIM DA MISSÃO DO AGENTE DIPLOMÁTICO}

Nesse particular é, igualmente, necessário fazer uma distinção inicial entre as missões especiais e as ordinárias.

Quanto às delegações especiais, ou extraordinárias, terminam normalmente pela execução da missão. Uma Embaixada Especial enviada a uma posse presidencial, coroação de monarca, casamento de membros de uma família reinante, entêrro de Chefe de Estado ou outra cerimônia análoga terminará a sua missão quando as solenidades tocarem ao seu fim. Se uma missão é enviada para negociar um tratado, dará por finda a missão com a aposição das assinaturas ou se verificar a impossibilidade da mesma.

A missão diplomática permanente pode findar de diversas maneiras: pele remoção do titular a novo pôsto, pela sua morte, aposentadoria ou disponibilidade; pela morte do soberano que o nomeou ou junto ao qual se acha acreditado; pela elevação de categoria da missão; ou se a retirada do agente é solicitada por haver sido considerado indesejável pelo Govêrno local.

De tôdas essas hipóteses, só a última merece uma menção mais detalhada. A regra geral é de que a missão do agente finda por medida do Estado de que depende. Só excepcionalmente o reverso ocorre quando o funcionário diplomático é considerado persona non grata. A Convenção de Havana sôbre funcionários diplomáticos, firmada a 20 de fevereiro de 1928, dispõe no art. 25, n. $^{\circ} 4$, que cessa a missão "pela entrega dos passaportes ao funcionário, feita pelo Govêrno perante o qual esteja acreditado".

O princípio está em harmonia com o art. $8 .^{\circ}$, o qual regula que os Estados podem negar-se a admitir um funcionário diplomático de outros, ou, já tendo admitido, pedir a sua retirada, sem ficarem obrigados a explicar os motivos da sua resolução.

Uma vez verificado o procedimento incorreto, o Estado interessado consulta em caráter confidencial o Estado representado pelo diplomata, solicitando a sua retirada. De um modo geral, esta é concedida, principalmente se as queixas se revestem de certa gravidade, visto que os Estados têm todo interêsse em manter relações de cordialidade com os demais membros de comunhão internacional.

O direito internacional é rico em exemplos, mas foge ao escopo dêsse trabalho mencioná-los.

A doutrina, baseada na prática, aceita a teoria em questão. Com efeito, o direito de despedida de agentes diplomáticos é, em parte, correlativo ao de exclusão. Já que um Estado tem o direito de aceder, ou não, a um pedido de aǵrément, poderá, uma vez verificado que a pessoa em questão não preenche os predicados necessários para o exercício de funções da magnitude das diplomáticas, pleitear a sua retirada.

O pedido, contudo, deverá ser vazado em têrmos comedidos e ser devidamente motivado. Neste particular, a orientação seguida pela Convenção 
de Havana sôbre funcionários diplomáticos é passível de críticas, pois estipula que aos Estados é lícito pedir a retirada de funcionários diplomáticos de outros sem obrigação de explicar os motivos determinantes de tal pedido.

Neste particular equiparou de modo absoluto a questão da exclusão ao da despedida de diplomatas. Embora se trate de dois direitos correlativos, nem sempre podemos aplicar os mesmos princípios a ambos os casos. A prática internacional, com a exceção da Grã-Bretanha, concede ao Estado ao qual é pedido um agrément a faculdade de não justificar a recusa do indigitado. A Convenção adotou a mesma regra, com relação a declaração de personalidade não grata. Variam as causas que poderão levar um Estado a pedir a retirada de um representante estrangeiro. O motivo poderá resultar da prática de um ato grave de consequêencias sérias, ou então da prática reiterada de atos ofensivos ao país.

Uma ingerência em trama atentatório contra a ordem interna do país, atos tendentes a provocar desentendimentos e até uma guerra com Nação amiga, enquadrar-se-iam na primeira hipótese, isto é, o envolvimento em trama de conseqüências sérias e capazes de colocar o país que deu acolhida ao diplomata numa situação vexatória.

Na segunda hipótese, temos motivos de natureza principalmente moral. Assim, reiteradas demonstrações públicas de desprêzo pelas autoridades, pelos costumes, pela sociedade do país em que serve. Falta de cortesia para com as autoridades locais, como não thes reconhecer os títulos a que têm direito, etc.

O Estado representado tem o direito, na hipótese de não concordar com o pedido de retirada de seu representante, de não atender ao pedido em questão.

Como Hall bem exprimiu: "A cortesia para corr. um Estado amigo estabelece que o representante de sua soberania não deve ser delicada ou acintosamente despedido. Se não é indicada a causa, ou se a mesma é inadequada, mostra-se pouca consideração à dignidade pessoal do seu Estado; se a causa é inconsistente ou falsa, poderá haver margem para crer na intenção de um insulto disfarçado. Assim, um país não necessita chamar seu agente, ou concordar com a sua demissão, a não ser que acredite terem as razões alegadas bastante fundamento." (20)

Se o Govêrno julgar que o pedido não se justifica, poderá, uma vez esgotados todos os recursos para mostrar a improcedência do alegado, remover o seu agente para outra missão de igual importância ou de categoria superior. Poderá ainda deixar a Missão entregue a um encarregado de negócios ad interim e continuar a considerar o indigitado como titular do pôsto. Ainda recentemente tal ocorreu com o Embaixador norte-americano em Moscou, cuja retirada fôra solicitada em vão pelo Govêrno soviético.

\section{BIBLIOGRAFIA}

(1) Direito Público Internacional, t. $10^{\circ}$ (2. ${ }^{a}$ edição - Rio de Janeiro - 1939) § 92 , pág. 330 .

(2) "Dictionnaire Diplomatique" da Acacémie Diplomatique Internationale (Paris), pág. 47 , col. 1. 
(3) apud P. FAUChIlle, Traité de Droit International Public, t. 1. ${ }^{\circ}$, 3ème partie (Paris 1926), n. ${ }^{\circ} 669$, pág. 42.

(4) HYDE: International Law t. $1^{\circ}$ (London), pág. 733, nota 3.

(5) John BASSETT MOORE: Digest of International Law, t. 4. ${ }^{\circ}$ (Washington), pág. 482.

(6) HILdebrando Accioly: Tratado de Derecho Internacional Público, tomo II (Rio de Janeiro - 1945), pág. 319, in nota.

(7) G. E. Do Nascimento E Silva: Têrmo de missão diplomática, no Boletim da Sociedadì Brasileira de Direito Internacional, ano 2 (1946), n. ${ }^{\circ} 4$, pági 55 !

(8) apud ARTHUR SANTos: A escolha de representantes junto a Organizações Internacionais, no Boletim da Sociedade Brasileira do Direito Internacional, ano 3 (1947), n. 6 , pág. 24 .

(9) op. cit., pág. 33.

(10) Paul Fauchille: Traité de Droit International Public, t. 1, 3ème partie (Paris 1926), n. ${ }^{\circ} 665$, pág. 38 .

(11) apud H. Accroly op. cit., pág. 318, in nota.

(12) Traité de Droit International Public, t. 2 (Paris - 1951) - pág. 13, in nota.

(13) Tratado de Direito Diplomático, tomo $1 .^{\circ}$ (Rio de Janeiro -- 1948), n. ${ }^{\circ} 156$, pág. 198.

(14) Rubens de Mello, op. cit. n. ${ }^{\circ}$ 156, pág. 199.

(15) Traité de Diplomatie et de Droit Diplomatique, tomo $2 .^{\circ}$ (Paris - 1931), n. ${ }^{\circ} 729$, pág. 191.

(16) Tratado de Derecho Internacional Público, t. 2. ${ }^{\circ}$, (Rio de Janeiro - 1946), n. ${ }^{\circ}$ 1.139-A, pág. 323.

(i7) op. cit., n. ${ }^{\circ} 669$, págs. 43-44.

(18) José Sebastian de ERICe y O'Shea: Normas de Diplomacia y de Derecho Diplomático, tomo 1 (Madrid - 1945)), pág. 57.

(19) G. E. Do Nascimento E Silva: La declaración de Guerra y sus efectos (Sinta Fé - Argentina - 1952), pág. 16.

(20) A treatise on international law (Oxford - 1924). 